\title{
Nickel Oxide Nanoparticles Trigger Caspase- and Mitochondria- Dependent Apoptosis in the Yeast Saccharomyces cerevisiae
}

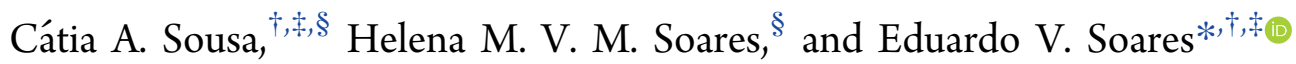 \\ ${ }^{\dagger}$ Bioengineering Laboratory-CIETI, Chemical Engineering Department, ISEP-School of Engineering of Polytechnic Institute of \\ Porto, Rua Dr António Bernardino de Almeida, 431, 4249-015 Porto, Portugal \\ ${ }^{\ddagger}$ CEB-Centre of Biological Engineering, University of Minho, Campus de Gualtar, 4710-057 Braga, Portugal \\ ${ }^{\S}$ REQUIMTE/LAQV, Departamento de Engenharia Química, Faculdade de Engenharia, Universidade do Porto, rua Dr. Roberto \\ Frias, 4200-465 Porto, Portugal
}

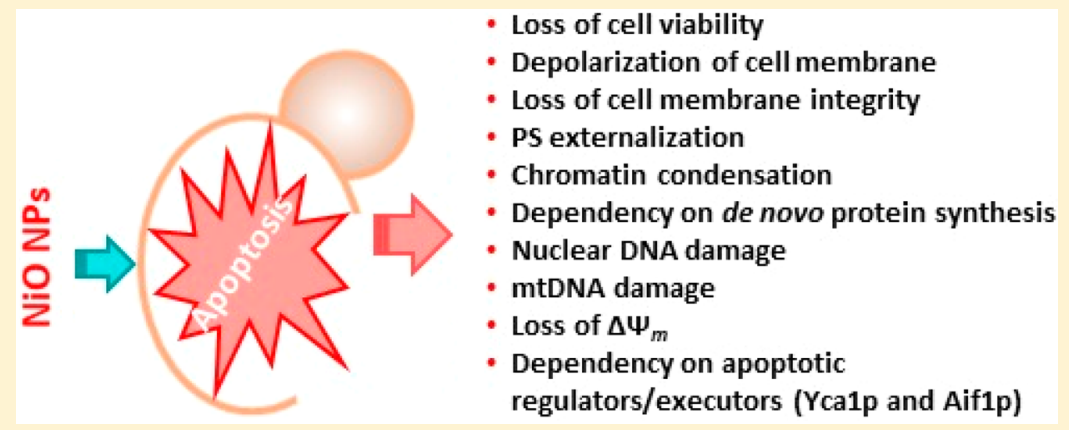

ABSTRACT: The expansion of the industrial use of nickel oxide (NiO) nanoparticles (NPs) raises concerns about their potential adverse effects. Our work aimed to investigate the mechanisms of toxicity induced by NiO NPs, using the yeast Saccharomyces cerevisiae as a cell model. Yeast cells exposed to NiO NPs exhibited typical hallmarks of regulated cell death (RCD) by apoptosis [loss of cell proliferation capacity (cell viability), exposure of phosphatidylserine at the outer cytoplasmic membrane leaflet, nuclear chromatin condensation, and DNA damage] in a process that required de novo protein synthesis. The execution of yeast cell death induced by NiO NPs is Ycalp metacaspase-dependent. NiO NPs also induced a decrease in the mitochondrial membrane potential and an increase in the frequency of respiratory-deficient mutants, which supports the involvement of mitochondria in the cell death process. Cells deficient in the apoptosis-inducing factor (aif1 $\Delta)$ displayed higher tolerance to NiO NPs, which reinforces the involvement of mitochondria in RCD by apoptosis. In summary, this study shows that NiO NPs induce caspase- and mitochondria-dependent apoptosis in yeast. Our results warn about the possible harmful effects associated with the use of NiO NPs.

\section{INTRODUCTION}

Because of their unique physiochemical properties and reactivity, metal oxide nanoparticles (NPs) have been manufactured in greater amounts in the past decade. Nickel oxide (NiO) NPs are used for multiple applications, such as catalysts, memory cells, electrode materials in multilayer ceramic capacitors, diesel-fuel additives, and pigments for ceramics and glasses. ${ }^{1}$ As the nanotechnology industry expands, exposure to NiO NPs emerges as a significant occupational hazard. In addition, a deeper understanding of the potential impact of NiO NPs on the environment and human health is required.

Adverse effects as a consequence of exposure to NiO NPs, such as cytotoxicity, inflammation, and genotoxicity in human pulmonary cells, have been reported. ${ }^{2-5}$ The International Agency for Research on Cancer classified nickel compounds as group 1 (carcinogenic to humans) and metallic nickel as group 2B (possibly carcinogenic to humans). ${ }^{6}$
Cell death can be classified into not programmed "accidental cell death" (ACD) and "regulated cell death" (RCD). The first subtype of cell death (ACD) occurs as a consequence of the exposure of cells to severe physical, chemical, or mechanical stimuli; cells die in an uncontrollable manner as a result of their immediate loss of structural integrity. RCD involves a genetically encoded machinery and can result from multiple signaling pathways, including apoptosis. The designation "programmed cell death" (PCD) is used to refer to RCD that occurs in specific physiological scenarios. ${ }^{7,8}$ Many human diseases, such as several neurological disorders (for example, Huntington's, Parkinson's, and Alzheimer's disease) and cancer, are associated with the dysregulation of cell death pathways. ${ }^{9}$ In this context, it has been shown that exposure to $\mathrm{NiO}$ NPs induces apoptosis in different cell lines, such as in

Received: September 17, 2018

Published: January 18, 2019 
human bronchial epithelial (BEAS-2B), ${ }^{10}$ lung epithelial $(\mathrm{NCIH} 460),{ }^{11}$ liver (HepG2), ${ }^{12,13}$ and neuronal (SH-SY5Y) cells. $^{14}$

The yeast Saccharomyces cerevisiae is a relevant eukaryotic cell model in different fields, such as biochemistry and molecular and cellular biology. In the past decade, this unicellular microorganism has been used in the study of RCD. ${ }^{15,16}$ This yeast displays some similarities (orthologues) with mammalian (including human) cells, which makes it an effective cell model for human diseases. ${ }^{17}$ In a previous work, it was found that exposure of $S$. cerevisiae cells to $\mathrm{NiO} N P s$ induced the loss of metabolic activity and cell viability in a dose-dependent manner. ${ }^{18}$ In a subsequent work, it was observed that the loss of cell viability induced by $\mathrm{NiO}$ could be attributed to the intracellular generation of reactive oxygen species (ROS) and glutathione depletion. ${ }^{19}$ It has been described that oxidative stress is a common denominator of RCD initiation. ${ }^{20}$ The work presented here aims to characterize the cell death observed in $S$. cerevisiae upon exposure to $\mathrm{NiO}$ NPs. For this purpose, yeast cell death induced by $\mathrm{NiO}$ NPs was assessed by monitoring the loss of plasma membrane integrity and cell viability. Subsequently, the presence of typical morphological and biochemical features of apoptotic cell death was examined in yeast cells exposed to a cytotoxic concentration of NiO NPs. In addition, the dependence of known apoptotic regulators/executors (Ycalp and Aiflp) in RCD induced by NiO NPs was evaluated.

\section{EXPERIMENTAL PROCEDURES}

Preparation of Nickel Oxide Nanoparticle Suspensions. Commercial NiO NPs (catalog no. 637130, with a particle size of $<50$ $\mathrm{nm}$ and a purity of $99.8 \%$, trace metal basis) were purchased from Sigma-Aldrich (St. Louis, MO).

$\mathrm{NiO} \mathrm{NP}$ stock suspensions (at $0.5 \mathrm{~g} / \mathrm{L}$ ) were prepared in deionized water, sterilized under an ultraviolet lamp for $30 \mathrm{~min}$, and stored at 4 ${ }^{\circ} \mathrm{C}$ (for up to one month). Before being tested, stock suspensions of $\mathrm{NiO}$ NPs were vigorously vortexed and sonicated for $1 \mathrm{~h}$ in an ultrasonic bath (80-160 W, Bandelin Sonorex RK 100).

Physicochemical characterizations of NiO NPs, namely, particle size and morphology, agglomeration, surface charge, and dissolution in $10 \mathrm{mM}$ 2-( $N$-morpholino)ethanesulfonic acid (MES) buffer (Sigma-Aldrich), were previously carried out. ${ }^{18}$

Strains, Media, Growth Conditions, and Treatments. Experiments were carried out using $S$. cerevisiae BY4741 (MAT $\alpha$; his $3 \Delta 1$; leu $2 \Delta 0$; met $15 \Delta 0 ; u r a 3 \Delta 0$ ) as a wild-type strain (WT); in addition, the respective knockout mutants in the AIF1 or YCA1 genes were also used. Strains were obtained from the European Saccharomyces cerevisiae Archive for Functional Analysis (EUROSCARF).

S. cerevisiae BY4741 was maintained at $4{ }^{\circ} \mathrm{C}$ on YPD agar containing $5 \mathrm{~g} / \mathrm{L}$ yeast extract (Difco-BD), $5 \mathrm{~g} / \mathrm{L}$ peptone (Difco$\mathrm{BD}), 10 \mathrm{~g} / \mathrm{L}$ glucose (Merck), and $15 \mathrm{~g} / \mathrm{L}$ agar (VWR Chemicals). The knockout strains were maintained on YPD agar with $0.2 \mathrm{~g} / \mathrm{L}$ Geneticin (G418 disulfate salt, Sigma-Aldrich). The assessment of respiratory-deficient $(\mathrm{RD})$ mutants (see below) was carried out using YPGly agar medium. YPGly agar is similar to YPD agar, with glucose being replaced with $2 \%(\mathrm{v} / \mathrm{v})$ glycerol (Merck). In the canavanine assay (see below), the synthetic dextrose (SD) minimal agar medium, ${ }^{21}$ containing $6.7 \mathrm{~g} / \mathrm{L}$ yeast nitrogen base without amino acids (Difco-BD), $20 \mathrm{~g} / \mathrm{L}$ glucose, $15 \mathrm{~g} / \mathrm{L}$ agar, $0.02 \mathrm{~g} / \mathrm{L}$ uracil (Sigma-Aldrich), $0.02 \mathrm{~g} / \mathrm{L}$ L-methionine (Sigma-Aldrich), $0.1 \mathrm{~g} / \mathrm{L} \mathrm{L}-$ leucine (Sigma-Aldrich), and $0.02 \mathrm{~g} / \mathrm{L}$ L-histidine $\mathrm{HCl}$ (SigmaAldrich) without or with $60 \mathrm{mg} / \mathrm{L}$ canavanine (Sigma-Aldrich) $\left(\mathrm{SD}_{+\mathrm{can}}\right)$, was used.

All strains were grown in YPD broth to exponential phase by incubating the cells overnight, to an $\mathrm{OD}_{600}$ of $\sim 1.0$, with continuous shaking $(150 \mathrm{rpm})$ at $30^{\circ} \mathrm{C}$.
After growth, cells were harvested by centrifugation $(2500 \mathrm{~g}, 5 \mathrm{~min})$, washed twice with water, resuspended at a density of $1 \times 10^{7}$ cells $/ \mathrm{mL}$ in $10 \mathrm{mM}$ MES buffer ( $\mathrm{pH} 6.0$ ) with $20 \mathrm{~g} / \mathrm{L}$ glucose, and incubated without (control) or with $100 \mathrm{mg} / \mathrm{L} \mathrm{NiO} \mathrm{NPs} \mathrm{at} 30^{\circ} \mathrm{C}$ and $150 \mathrm{rpm}$ for $\leq 48 \mathrm{~h}$.

The effect of $25 \mathrm{mg} / \mathrm{L}$ cycloheximide (cyh, Sigma-Aldrich) on the toxicity induced by $\mathrm{NiO}$ NPs was assessed by preincubation with this compound for $30 \mathrm{~min}$ before exposure to $\mathrm{NiO} \mathrm{NPs}$. Control experiments have shown that, at the concentration used, cycloheximide was not toxic to yeast cells.

Survival Assay. The effect of NiO NPs on yeast cells was assessed by a cell viability assay (clonogenic test), as previously described. ${ }^{18}$ Briefly, after exposure to NiO NPs, yeast cells were serially diluted in deionized water, plated on YPD agar, and incubated for $72-96 \mathrm{~h}$ at 30 ${ }^{\circ} \mathrm{C}$. Cell viability was calculated considering the number of colonyforming units (CFUs) per milliliter at time zero as a reference (100\%).

Evaluation of Plasma Membrane Integrity. Plasma membrane permeability was assessed using the nonpermeant propidium iodide (PI) probe. Yeast cells $\left(1 \times 10^{7}\right.$ cells $\left./ \mathrm{mL}\right)$ were incubated with 4.5 $\mu \mathrm{M}$ PI (Sigma) for $10 \mathrm{~min}$ at room temperature in the dark.

The plasma membrane potential was monitored by staining the cells with bis-1,3-dibutylbarbituric acid trimethine oxonol $\left[\mathrm{DiBAC}_{4}(3)\right]$, known as Oxonol (Oxo) (Molecular Probes, Invitrogen $){ }^{22}$ Yeast cells $\left(1 \times 10^{7}\right.$ cells $\left./ \mathrm{mL}\right)$ were incubated with $1.94 \mu \mathrm{M}$ Oxo (final concentration) for $10 \mathrm{~min}$ at $30^{\circ} \mathrm{C}$ in the dark. In the double-staining protocol (Oxo/PI), cells were first stained with Oxo and, subsequently, with PI, as described above.

As a positive control (cells with a depolarized and permeabilized membrane), yeast cells were heated at $65^{\circ} \mathrm{C}$ for $1 \mathrm{~h}$.

The percentage of PI or Oxo negative cells was determined with a fluorescence microscope (Leica DLMB), equipped with an HBO-100 mercury lamp and filter set I3 [excitation filter (band-pass filter, BP) BP 450-490, dichromatic mirror 510, and suppression filter (long pass filter, LP) LP 515] from Leica. Doubly stained (Oxo/PI) yeast cells were observed using filter set I3, GFP (excitation filter BP 450490 , dichromatic mirror 500, and suppression filter BP 500-550), or N2.1 (excitation filter BP 515-560, dichromatic mirror 580, and suppression filter LP 590) from Leica. In each experiment, two samples of at least 200 cells (total of $\geq 400$ cells) were counted in randomly selected microscope fields.

Images were acquired with a Leica DC $300 \mathrm{~F}$ camera and processed using Leica IM 50-Image Manager software.

Annexin V Staining. Annexin V [fluorescein isothiocyanate (FITC), FITC-conjugated], a protein that specifically binds to phosphatidylserine (PS) residues, was used to detect the externalization of PS. ${ }^{23}$ After treatment, yeast cells were collected, washed

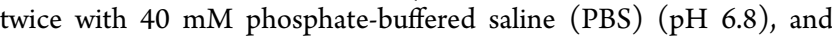
resuspended at a density of $1 \times 10^{7}$ cells $/ \mathrm{mL}$ in sorbitol buffer $[1.2 \mathrm{M}$ sorbitol, $0.5 \mathrm{mM} \mathrm{MgCl}$, and $35 \mathrm{mM} \mathrm{K} \mathrm{HPO}_{4}$ (pH 6.8)]. Cell walls were digested by incubation with 90 units/mL lyticase (SigmaAldrich) in sorbitol buffer for $45 \mathrm{~min}$ at $28{ }^{\circ} \mathrm{C}$. Then, cell suspensions $(1 \mathrm{~mL})$ were centrifuged $(250 \mathrm{~g}, 5 \mathrm{~min})$, resuspended in $60 \mu \mathrm{L}$ of incubation buffer (containing the Annexin-V-FLUOS labeling solution and PI) (Roche), and incubated for $10 \mathrm{~min}$ at $25{ }^{\circ} \mathrm{C}$. Cells were observed in a fluorescence microscope using filter set I3. In each experiment, two samples containing at least 100 cells (total of $\geq 200$ cells) were counted in randomly selected microscope fields. Images were acquired and processed as described above.

Assessment of the Mitochondrial Membrane Potential. The evaluation of the mitochondrial membrane potential $\left(\Delta \Psi_{\mathrm{m}}\right)$ was carried out using the probe $3,3^{\prime}$-dihexyloxacarbocyanine iodide $\left[\mathrm{DiOC}_{6}(3)\right]$ (Sigma-Aldrich). ${ }^{24,25}$ Yeast cells $\left(1 \times 10^{7}\right.$ cells $\left./ \mathrm{mL}\right)$ were collected and incubated with $30 \mathrm{nM} \mathrm{DiOC}_{6}(3)$ for $20 \mathrm{~min}$ at 30 ${ }^{\circ} \mathrm{C}$ in the dark. Then, the cells were dispensed (200 $\mu \mathrm{L}$ per well), in quintuplicate in a 96-well flat microplate (Orange Scientific). The fluorescence intensity [in relative fluorescence units (RFUs)] was measured in a PerkinElmer (Victor3) microplate reader at a fluorescence excitation wavelength of $485 / 14 \mathrm{~nm}$ and an emission wavelength of $535 / 25 \mathrm{~nm} . \Delta \Psi_{\mathrm{m}}$ was expressed as the ratio between 

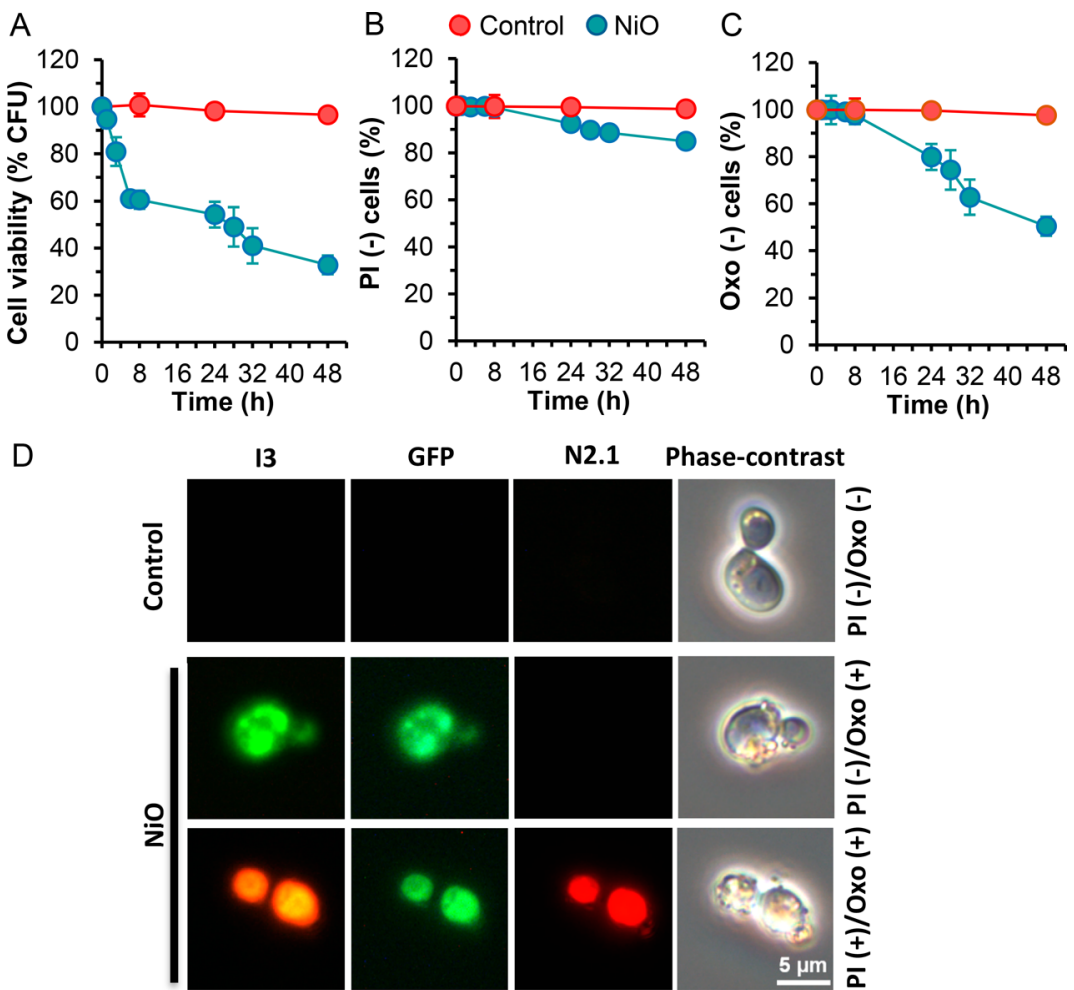

Figure 1. Cell viability and plasma membrane integrity in yeast cells of S. cerevisiae BY4741 exposed to NiO NPs. Cells were suspended in MES buffer in the absence (control) or presence of $100 \mathrm{mg} / \mathrm{L} \mathrm{NiO} \mathrm{NPs.} \mathrm{(A)} \mathrm{Cell} \mathrm{viability} \mathrm{evaluated} \mathrm{by} \mathrm{colony-forming} \mathrm{unit} \mathrm{(CFU)} \mathrm{counting.} \mathrm{(B)}$ Membrane permeability assessed by propidium iodide (PI) exclusion. (C) Membrane polarization monitored by Oxonol (Oxo) exclusion. (D) Photomicrographs of cells not exposed (control) or exposed to $100 \mathrm{mg} / \mathrm{L} \mathrm{NiO}$ for $24 \mathrm{~h}$ and then doubly stained with PI and Oxo. Cells were visualized by fluorescence, using filter set I3 (green and orange-red fluorescence), GFP (green fluorescence), or N2.1 (orange-red fluorescence), or by phase contrast microscopy. The data represent the means $( \pm S D)$ of at least three independent experiments.

the fluorescence in the assay and the fluorescence in the control (nontreated cells).

Cells were also doubly stained with $\operatorname{DiOC}_{6}(3)$ and PI. After $\mathrm{DiOC}_{6}(3)$ staining, cells were incubated with PI, as described above. Stained cells were observed in an epifluorescence microscope equipped with filter set GFP $\left[\operatorname{DiOC}_{6}(3)\right]$ or N2.1 (PI). Images were acquired and processed as described above.

Evaluation of Nuclear Alterations. After treatment with $\mathrm{NiO}$ NPs, cells were fixed with $3.5 \%(\mathrm{w} / \mathrm{v})$ formaldehyde, stained with 3 $\mu \mathrm{M}$ diaminophenylindole (DAPI) (Sigma-Aldrich) for $15 \mathrm{~min}$ at room temperature in the dark, and mounted with ProLong Gold antifade reagent (Molecular Probes, Invitrogen), as previously described. ${ }^{26}$ Cells were observed in an epifluorescence microscope equipped with filter set A (excitation filter BP 340-380, dichromatic mirror 400, and suppression filter LP 425) from Leica. In each experiment, two samples containing at least 200 cells (total of $\geq 400$ cells) were evaluated in randomly selected microscope fields. Images were acquired and processed as described above.

Mitochondrial Mutation Assay. The quantification of $\mathrm{RD}$ mutants induced by NiO NPs was assessed by the complete lack of growth of these mutants on nonfermentable medium (YPGly). ${ }^{27,28}$ Appropriate dilutions of cell suspensions were plated on YPD and YPGly. The percentage of $\mathrm{RD}$ cells was calculated as previously described. ${ }^{29}$

Nuclear DNA Mutation Rate Detection (canavanine assay). The rate of mutation induced by $\mathrm{NiO}$ NPs was determined by the selection of inactivation of the permease CAN1 gene (canavanine assay $).^{30}$ Cell suspensions $\left(1 \times 10^{7}\right.$ cells $\left./ \mathrm{mL}\right)$ were appropriately diluted and plated on a medium without arginine but with $60 \mathrm{mg} / \mathrm{L} \mathrm{L}_{\mathrm{L}}$ canavanine $\left(\mathrm{SD}_{+\mathrm{can}}\right)$. In parallel, convenient dilutions of the cell suspensions were plated on the same medium (SD) without canavanine. The plates were incubated for $5-7$ days at $30^{\circ} \mathrm{C}$. The frequency of mutation was calculated considering the number of $\mathrm{CFU}$ per milliliter on $\mathrm{SD}_{+ \text {can }}$ plates $\left(\mathrm{Can}^{\mathrm{R}}\right.$ cells $)$ and the number of $\mathrm{CFU}$ per milliliter on SD plates (total viable cells).

Reproducibility of the Results and Statistical Analysis. All experiments were performed at least three times in duplicate. The data are presented as mean values \pm standard deviations $(\mathrm{SD})$; where no error bars are shown, SDs are within the points. In the experiment in which fluorescence was quantified, a typical example of an experiment repeated at least three times is presented; each datum represents the mean $( \pm S D)$ of five fluorescent readings.

Statistical differences between control and treated cells were tested using an unpaired $t$ test. $P$ values of $<0.05$ were considered statistically significant.

\section{RESULTS}

Impact of NiO NPs on Cell Viability and Plasma Membrane Integrity. Cell viability was evaluated by quantification of the reduction of the number of CFUs after different periods of contact time of yeast with $\mathrm{NiO}$ NPs. Exposure to $\mathrm{NiO} \mathrm{NPs}$ induced an abrupt loss of cell cultivability. Cell viability dropped to $\sim 60 \%$ in the first $8 \mathrm{~h}$ (Figure 1A); later exposure to $\mathrm{NiO} \mathrm{NPs}$ induced a slower reduction in cell viability, $\sim 33 \%$ of the cells being viable at 48 h (Figure 1A).

To define a lethal scenario in yeast cells exposed to $\mathrm{NiO}$ NPs, a kinetic assessment of cell membrane integrity was carried out through the monitoring of PI uptake. It is assumed that viable cells exclude PI (PI negative cells) (Figure 1D, control). As one can see in Figure 1B, a small proportion of the cell population (2\%) remained permeable to PI after contact with $\mathrm{NiO} \mathrm{NPs}$ for $8 \mathrm{~h}$. 
The uptake of PI requires significant damage to the cell membrane. This means that the permeability to PI represents irreparable damage of the plasma membrane (permanent loss of barrier function $)^{31}$ and cell death. ${ }^{7,32}$ On the other hand, it has also been reported that the uptake of the lipophilic anionic probe $\operatorname{DiBAC}_{4}(3)$, known as Oxonol (Oxo), occurs in less damaged cells ${ }^{33}$ with a reduced membrane potential (depolarized cell membrane). ${ }^{22,34}$ Nonstressed cells displayed a polarized membrane that remained unstained (Oxo negative cells) (Figure 1D, control). To obtain further information about the impact of $\mathrm{NiO}$ on the yeast plasma membrane, after exposure to NPs, cells were stained with Oxo. The exposure of yeast cells to NiO NPs for $\leq 8 \mathrm{~h}$ did not have any impact on the plasma membrane potential, as cells remained Oxo negative (Figure 1C). After this time, the cells became permeable to Oxo. Thus, after exposure to NPs for 24 and 48 $\mathrm{h}, \sim 20$ and $\sim 50 \%$ of the cell population were Oxo positive, respectively (Figure $1 \mathrm{C}$ ). After the same period of exposure to NPs, $\sim 8$ and $15 \%$ of the yeast cells were PI positive, respectively (Figure 1B). Comparative analysis of the cells stained with Oxo and PI revealed that there was a fraction of cells which membrane presented a reduced potential, becoming Oxo positive, although they maintained their impermeability to PI (Figure 1B,C). These results indicate that under $\mathrm{NiO}$ stress, de-energization precedes permeabilization of the cell membrane. This possibility was confirmed by fluorescence microscopic observation of the yeast cells exposed to NPs and doubly stained with Oxo and PI, where it was possible to detect PI negative/Oxo positive cells (Figure 1D). However, all cells that were PI positive presented a depolarized membrane (Oxo positive) (Figure 1D). Altogether, the results show that the loss of cultivability preceded the loss of membrane potential and plasma membrane integrity (Figure S1).

After the exposure of yeast cells to NiO NPs for $24 \mathrm{~h}, \sim 8 \%$ of yeast cells have passed the "point of no return", 35 as they exhibited irreversible plasma membrane permeabilization (PI positive cells) and thus can be classified as dead. ${ }^{7}$ At this time ( $24 \mathrm{~h}$ ), although only $\sim 55 \%$ of the cell population displayed the ability to undergo proliferation (Figure 1A and Figure S1), $\sim 80 \%$ of the cell population had intact membranes (PI negative/Oxo negative) and, thus, can be classified as viable, which suggests RCD in yeast cells exposed to NiO NPs. These results prompted us to further characterize the cell death phenotype NiO NPs induced through the assessment of different morphological and biochemical features.

NiO NPs Induce Cell Death with Typical Apoptotic Hallmarks. In a previous work, yeast cells exposed to $\mathrm{NiO}$ NPs presented an intracellular overload of reactive oxygen species (ROS), ${ }^{19}$ which can mediate yeast cell death by apoptosis. To confirm this possibility, yeast cells exposed to $\mathrm{NiO}$ NPs were doubly stained with Annexin V-FITC and PI to detect the externalization of phosphatidylserine (PS). The exposure of PS at the outer leaflet of the plasma membrane (loss of membrane asymmetry) is considered an early sign of apoptosis and one of the most reliable apoptosis markers. ${ }^{36}$ Cells that were Annexin V positive and PI negative (Figure 2A) are considered apoptotic. ${ }^{15}$ As one can see in Figure $2 \mathrm{~B}$, after exposure to NiO NPs for $6 \mathrm{~h}$, the percentage of yeast cells that were Annexin V positive and PI negative was significantly different from the control; after this time, an increase in the number of apoptotic cells was observed.
A

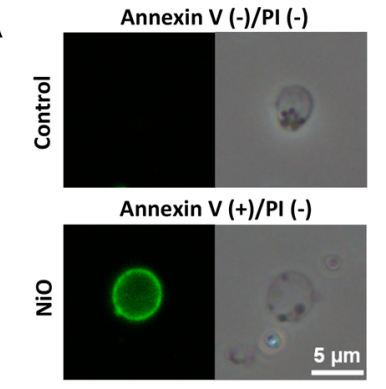

C
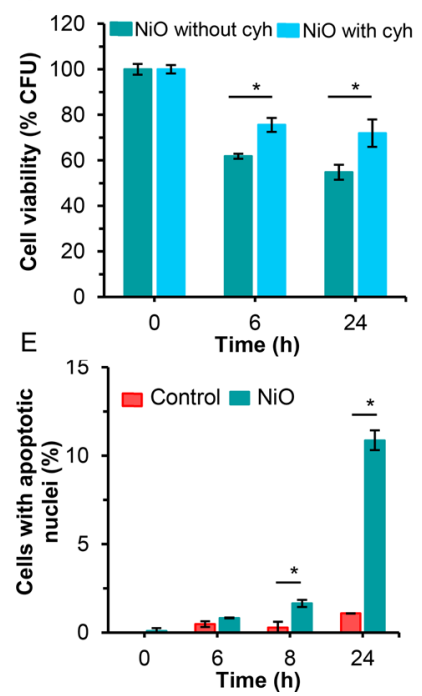

$\mathrm{B}$
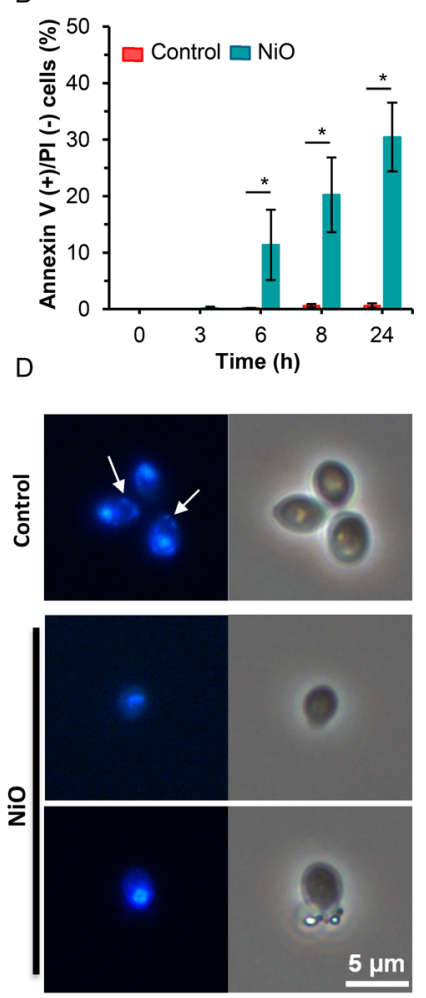

Figure 2. S. cerevisiae BY4741 cells exposed to NiO NPs exhibited typical apoptotic hallmarks. Cells were suspended in MES buffer in the absence (control) or presence of $100 \mathrm{mg} / \mathrm{L} \mathrm{NiO} \mathrm{NPs.} \mathrm{(A)}$ Visualization of cells doubly stained with Annexin V-FITC and PI. Fluorescence microscopy and respective phase contrast images (right). (B) Evolution of the percentage of apoptotic cells (Annexin positive and PI negative). (C) Cell viability, in the absence ( $\mathrm{NiO}$ without cyh) or presence ( $\mathrm{NiO}$ with cyh) of the protein synthesis inhibitor cycloheximide (cyh), evaluated by CFU counting. (D) Photomicrographs of cells stained with DAPI. Fluorescence microscopy and respective phase contrast images (right). Control cells presented homogeneous round nucleui and mitochondria (arrows). Mitochondria appeared as small dots predominantly located at the periphery of the cells. Cells treated with NiO NPs for $24 \mathrm{~h}$ displayed kidney-shaped (middle) or ring-shaped (bottom) nuclei, characteristic of apoptotic cells; in these cells, it was not possible to visualize mtDNA. (E) Determination of cells exhibiting chromatin condensation (apoptotic nuclei) monitored by fluorescence microscopy after DAPI staining. The data represent the means $( \pm S D)$ of at least three independent experiments. Mean values are significantly different: ${ }^{*} P<0.05$ in comparison with untreated cells (control); unpaired $t$ test.

Another feature of apoptosis is the requirement of de novo protein synthesis. ${ }^{37-41}$ To test this possibility, the effect of cyh, a protein synthesis inhibitor in eukaryotes, ${ }^{42}$ on RCD induced by NPs was investigated. Yeast cells were incubated for 6 or 24 $\mathrm{h}$ with $\mathrm{NiO}$ in the presence or absence of $25 \mathrm{mg} / \mathrm{L}$ cyh, and CFUs were counted. NiO- and cyh-treated cells displayed a higher percentage of CFUs compared to the NiO-treated cells in the absence of cyh (Figure 2C). This result suggests that the loss of cell viability in response to NPs stress requires the participation of cellular machinery, namely de novo protein synthesis, which is consistent with an apoptotic program. 

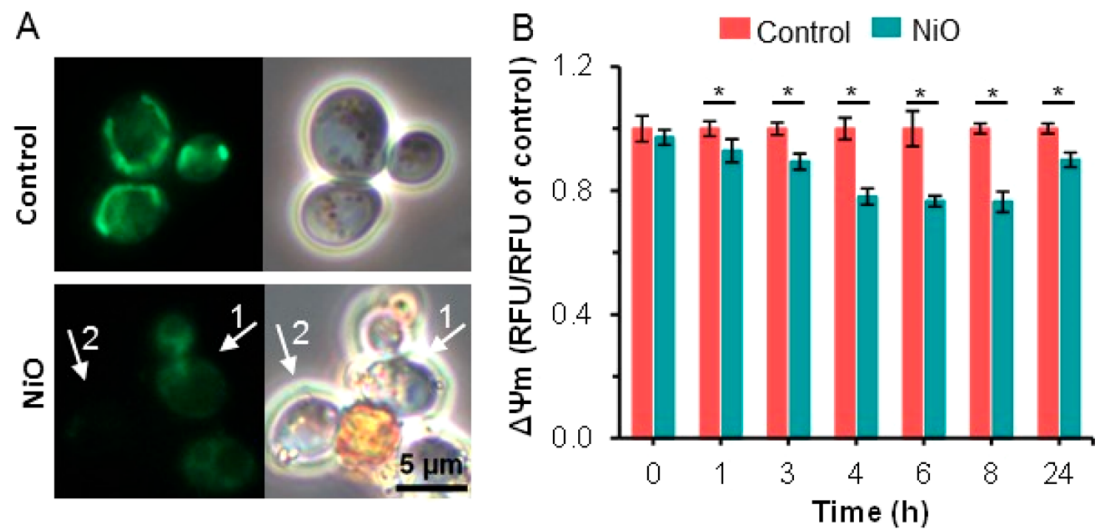

Figure 3. NiO NPs induce depolarization of the mitochondrial membrane in S. cerevisiae BY4741. Cells were exposed for $24 \mathrm{~h}$ in the absence (control) or presence of $100 \mathrm{mg} / \mathrm{L} \mathrm{NiO} \mathrm{NPs} \mathrm{and,} \mathrm{subsequently,} \mathrm{stained} \mathrm{with} \mathrm{DiOC}_{6}(3)$. (A) Visualization of yeast cells. Arrow 1 denotes cells with decreased green fluorescence; arrow 2 denotes a cell in which $\mathrm{DiOC}_{6}(3)$ failed to accumulate. Fluorescence microscopy (left) and respective phase contrast images (right). (B) Mitochondrial membrane potential $\left(\Delta \Psi_{\mathrm{m}}\right)$ monitored with the probe $\operatorname{DiOC}_{6}(3)$. This is a typical example of an experiment performed at least three times. The data represent the means $( \pm \mathrm{SD})$ of five fluorescent readings. Mean values marked with asterisks are significantly different $(P<0.05)$.

Apoptotic cells present condensed chromatin and modification of the shape of the nucleus as a consequence of the proteolysis of key nuclear proteins. ${ }^{43}$ To evaluate if NiO NPs induce chromatin condensation and modification of the morphology of the nucleus, nontreated (control) and NiOtreated yeast cells were stained with the DNA-binding dye DAPI. Fluorescence microscopy observations revealed that $\mathrm{NiO}$-treated yeast cells displayed ring- and kidney-shaped condensed chromatin, characteristic of apoptotic cells (Figure 2D). Control cells displayed homogeneous round nuclei (Figure 2D). A yeast population exposed for $8 \mathrm{~h}$ to $\mathrm{NiO}$ NPs presented a percentage of cells with apoptotic nuclei significantly different from those of the control (cells not exposed to $\mathrm{NiO}$ ); the percentage of cells with apoptotic nuclei increased with NP exposure duration (Figure 2E).

Altogether, the results presented above indicate that $\mathrm{NiO}$ NPs induced an apoptotic phenotype in yeast cells.

NiO NPs Induce Mitochondrial Membrane Depolarization. It has been shown that mitochondria play a central role in the execution of RCD by apoptosis in yeast cells. ${ }^{40,44-47}$ Modification of $\Delta \Psi_{\mathrm{m}}$ led to the disruption of mitochondrial function. In the work presented here, $\Delta \Psi_{\mathrm{m}}$ was assessed by quantification of the fluorescence of cells stained with the membrane potential-sensitive probe $\mathrm{DiOC}_{6}(3)$. This probe accumulates in the negatively charged mitochondrial matrix, and the extent of its uptake, as measured by the intensity of cellular fluorescence, reflects the $\Delta \Psi_{\mathrm{m}}{ }^{25,48}$ The observation of the control cells by fluorescence microscopy allowed the visualization of the typical mitochondrial networks as a result of the polarization of the inner mitochondrial membrane (Figure 3A). Fluorescence quantification revealed that after exposure to NiO NPs for $1 \mathrm{~h}$, yeast cells presented a progressive reduction in fluorescence $(\leq 6-8 \mathrm{~h})$, compared to that of control cells (Figure 3B). These results indicate that $\mathrm{NiO} \mathrm{NPs}$ induce the depolarization of the mitochondrial membrane. Microscopic observation of cells exposed to NPs for $8 \mathrm{~h}$ confirmed the presence of yeast cells with decreased green fluorescence and even the presence of yeast cells in which $\operatorname{DiOC}_{6}(3)$ failed to accumulate (Figure $3 \mathrm{~A}$ ) probably as a consequence of the dissipation of the mitochondrial membrane potential. Yeast cells exposed to NiO NPs for 24 $\mathrm{h}$ presented a fluorescence higher than that of cells exposed for
6-8 h (Figure 3B). However, this increase in fluorescence can be explained by the presence of some cells exhibiting a strong green fluorescence, all over the cells, as a result of the accumulation of $\operatorname{DiOC}_{6}(3)$ in the cytosol and not due to the repolarization of the mitochondrial membrane. Double staining of these cells with $\operatorname{DiOC}_{6}(3)$ and PI confirmed that the strongly fluorescent cells presented a permeabilized plasma membrane (PI positive cells) (Figure S2).

NiO NPs Induce Yca1p- and Aif1p-Dependent Apoptosis. To better characterize RCD, the effect of $\mathrm{NiO}$ NPs on the cell viability of knockout mutant strains $y c a 1 \Delta$ and aif $1 \Delta$, devoid of protein known to be involved in apoptotic cell death, was evaluated.

The proteases known as caspases are usually activated in the early stages of apoptosis and play a pivotal role in yeast cell death execution. ${ }^{49,50}$ Yeast cells bear the metacaspase Ycalp, which is an ortholog of mammalian caspases. ${ }^{51}$ The disruption of the YCA1 gene ( $y$ cal $\Delta$ strain) renders cells significantly more resistant to the toxic effect of the NPs (Figure 4), which suggests that $\mathrm{NiO}$-induced cell death is caspase-dependent.

The apoptosis-inducing factor (Aiflp) is a flavoprotein with $\mathrm{NADH}$ oxidase activity localized in the mitochondrial

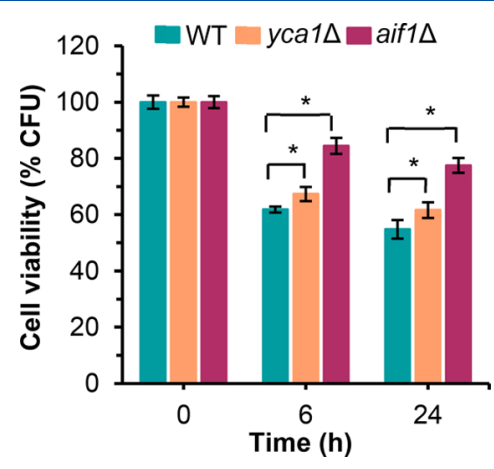

Figure 4. NiO NPs induce Ycalp- and Aiflp-dependent cell death in S. cerevisiae BY4741. Viability evaluated by CFU counting of wild-type (WT), $y c a 1 \Delta$, and aif $1 \Delta$ exposed to $100 \mathrm{mg} / \mathrm{L} \mathrm{NiO} \mathrm{NPs}$. The data represent the means $( \pm \mathrm{SD})$ of at least three independent experiments. Mean values are significantly different: $* P<0.05$ in comparison with untreated cells (control); unpaired $t$ test. 
intermembrane space of healthy cells; yeast Aiflp undergoes a translocation to the nucleus upon induction of apoptosis. ${ }^{52}$ As one can see in Figure 4, the aif $1 \Delta$ strain exhibited enhanced survival in response to $\mathrm{NiO} \mathrm{NPs}$ compared to that of the WT strain; this fact suggests the involvement of this mitochondrial apoptotic regulator in RCD induced by $\mathrm{NiO}$ NPs.

Altogether, the results presented above argue in favor of the involvement of the metacaspase Ycalp and the mitochondrial apoptotic factor Aiflp in the execution of apoptosis induced by $\mathrm{NiO}$ NPs.

NiO NPs Induce Mitochondrial and Nuclear DNA Damage. Mitochondrial DNA (mtDNA) encodes several subunits of the electron respiratory chain. ${ }^{53,54}$ The damage of mtDNA leads to the abolishment of respiration (formation of $\mathrm{RD}$ cells, also known as petite mutants). $\mathrm{RD}$ cells are unable to grow on nonfermentable carbon sources, such as glycerol. ${ }^{55}$ In a previous work, it was found that the mitochondrion is the main source of intracellular ROS induced by NiO NPs. ${ }^{19}$ Because mtDNA is very susceptible to oxidative injury, ${ }^{56}$ the possibility of the mitochondrial genome being damaged upon exposure to $\mathrm{NiO}$ was evaluated by determining the percentage of $\mathrm{RD}$ cells. As one can see in Figure $5 \mathrm{~A}$, the percentage of $\mathrm{RD}$

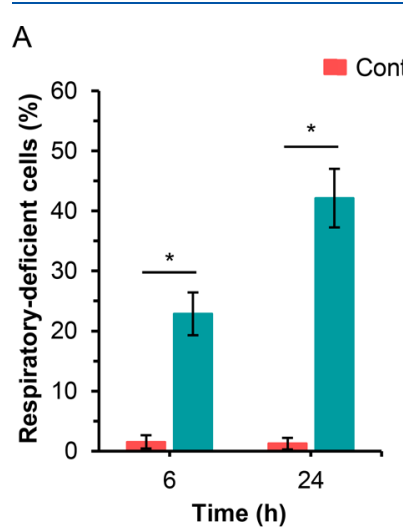

\section{B}

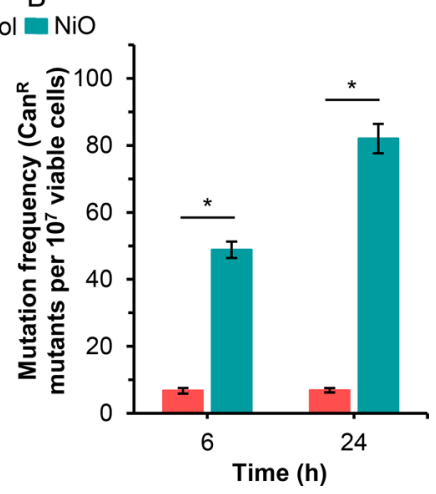

Figure 5. NiO NPs induce mitochondrial and nuclear DNA damage in S. cerevisiae BY4741. Cells were suspended in MES buffer in the absence (control) or presence of $100 \mathrm{mg} / \mathrm{L} \mathrm{NiO} \mathrm{NPs.} \mathrm{(A)}$ Mitochondrial DNA damage assessed through the formation of respiratory-deficient cell mutants (cells without the capacity to grow on a nonfermentable carbon source, YPGly). (B) Nuclear DNA damage evaluated through the formation of canavanine resistant $\left(\mathrm{Can}^{\mathrm{R}}\right)$ mutants. The data represent the means $( \pm \mathrm{SD})$ of at least three independent experiments. Mean values are significantly different: $* P<0.05$ in comparison with untreated cells (control); unpaired $t$ test.

cells increased with NiO NP exposure duration. Consistent with this result, the presence of cells lacking mtDNA (as revealed by DAPI staining) in the population exposed to NPs for $24 \mathrm{~h}$ (Figure 2D, NiO-treated cells) was observed. In control cells, the percentage of $\mathrm{RD}$ cells remained approximately constant (2\%), which corresponded to the values usually described for the spontaneous formation of these mutants. ${ }^{57}$ The results obtained indicate the damage of mtDNA, which means that the mitochondrial genome is one of the targets of the ROS generated in the mitochondria.

The canavanine assay was used to evaluate the possible damage of nuclear DNA due to intracellular ROS accumulation in yeast cells exposed to $\mathrm{NiO}$. This assay is based on the mutation in the plasma membrane arginine permease (encoded by CAN1), which originates in cells ( can $^{\mathrm{R}}$ mutants) resistant to L-canavanine (an analogue of $\mathrm{L}$-arginine).$^{58}$ It was possible to observe an increase of the number of $\mathrm{Can}^{\mathrm{R}}$ colonies (among the population of viable cells) in cells exposed to $\mathrm{NiO}$ NPs compared to the control. The mutation frequency induced by NiO NPs increased with exposure duration: after exposure to NiO NPs for 6 and $24 \mathrm{~h}$, the frequency of $\mathrm{Can}^{\mathrm{R}}$ mutations was approximately 7 - and 12-fold higher, respectively, compared with that of cells not exposed to $\mathrm{NiO}$ NPs (Figure 5B). These results demonstrate the damage of nuclear DNA by $\mathrm{NiO}$ NPs. In the control, the frequency of $\mathrm{Can}^{\mathrm{R}}$ mutations was similar after 6 and $24 \mathrm{~h}\left(7\right.$ per $10^{7}$ viable cells), which is similar to the rate described in the literature $\left(10-20\right.$ per $10^{7}$ viable cells $) .{ }^{59}$

\section{DISCUSSION}

The level of manufacturing and use of metal oxide NPs, such as $\mathrm{NiO} \mathrm{NPs}$, has increased greatly in the past decade and, inevitably, raised concerns and uncertainties about the possible adverse effects of NPs on the environment and human health. In a previous work, it was proposed that NiO NPs exert their toxic effect on yeast cells by an indirect mechanism: NiO NPs adsorb to the cell wall and release nickel at the NP-cell wall interface, producing a toxic response. ${ }^{18}$ To date, little has been known about the mechanisms underlying the loss of yeast cell viability induced by $\mathrm{NiO}$ NPs. To understand deeply the mechanism of the toxicity induced by $\mathrm{NiO} \mathrm{NPs}$, the wellknown apoptotic model $S$. cerevisiae was used.

It was shown that the exposure of yeast cells to NiO NPs for $\leq 24 \mathrm{~h}$ induced a loss of cell proliferation (cell viability) without disrupting cell membrane integrity (Figure 1). However, extending the exposure of yeast cells to $\mathrm{NiO}$ yielded cell death (plasma membrane breakdown, assessed through PI staining) (Figure 1). It was also found that yeast cells exposed to NPs lost their plasma membrane asymmetry (PS exposure to the outer membrane leaflet) (Figure 2). The loss of cell viability induced by $\mathrm{NiO}$ required the involvement of the metacaspase Ycalp (Figure 4) and was attenuated by the presence of a protein synthesis inhibitor (cyh) (Figure 2C). All of these features are typical hallmarks of RCD by apoptosis in yeast cells. ${ }^{32,39,49}$ Our results are in agreement with those that described the PS externalization ${ }^{10,14}$ and the involvement of caspase- 3 in apoptosis induced by NiO NPs in mammalian cell lines. $^{10-12,60}$ These results also suggest that $S$. cerevisiae and mammalian cell lines, exposed to $\mathrm{NiO} N$ Ps, share some common apoptotic features.

In a previous work, it was observed that antioxidants [Lascorbic acid (an efficient scavenger of free radicals) ${ }^{61,62}$ and $N$-tert-butyl- $\alpha$-phenylnitrone, known as PBN (a free radical spin trapping agent) $]^{63}$ prevented ROS overload and almost fully abolished the loss of cell viability induced by $\mathrm{NiO} \mathrm{NPs}^{19}$ these results strongly suggest that oxidative damage plays a central role in yeast cell death. The increased level of ROS, previously observed, was most likely the origin of the damage of the nuclear DNA (observed through the increase in the number of $\operatorname{can}^{\mathrm{R}}$ mutants) (Figure $5 \mathrm{~B}$ ). Our results are in agreement with those describing DNA damage in human cell lines exposed to $\mathrm{NiO} \mathrm{NPs} .^{2,12,14,60}$ In addition, in the work presented here, the induction of RD mutants in yeast cells exposed to NPs was shown (Figure 5A), which can also be attributed to the increased ROS levels in these cells. The loss of part or all of the mtDNA was further confirmed through the observation by fluorescence microscopy of yeast cells stained 


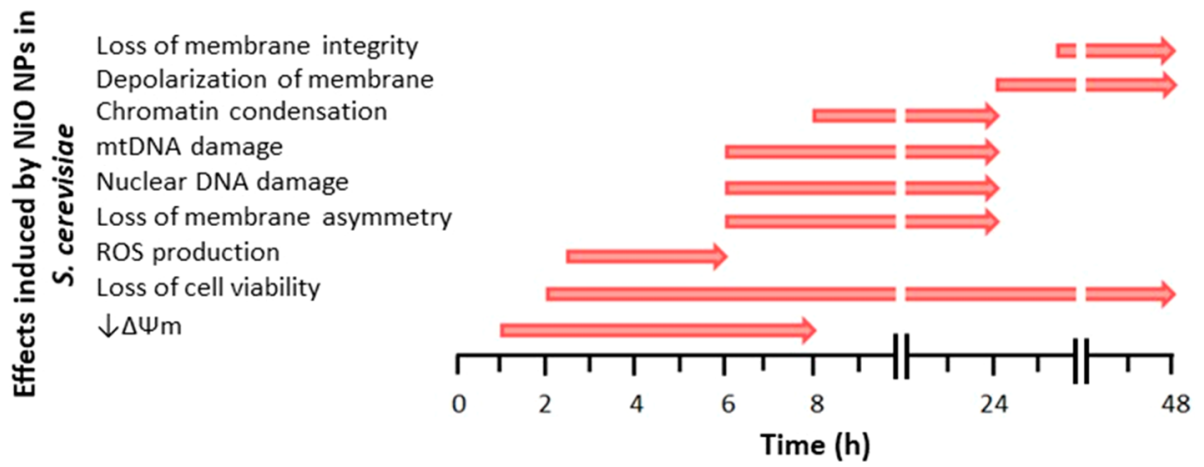

Figure 6. Sequence of events associated with NiO NP-induced cell death in S. cerevisiae. Proposal based on the results obtained in this work and previous work. ${ }^{18,19}$

with DAPI; in the cells exposed to $\mathrm{NiO}$ for $24 \mathrm{~h}$, it was not possible to visualize mtDNA (Figure $2 \mathrm{D}, \mathrm{NiO}$-treated cells).

The involvement of mitochondria in yeast apoptosis upon exposure to different stimuli has been described. ${ }^{38,44,45}$ Consistent with the possibility of NiO NPs inducing mitochondria-dependent apoptosis, in a previous work, it was shown that the mitochondria is the main contributor for ROS production. ${ }^{19}$ Here, it is described mitochondrial membrane depolarization (Figure 3), most likely, as a consequence of the permeabilization of the membrane. The dissipation of $\Delta \Psi_{\mathrm{m}}$ and the preservation of cell membrane integrity (Figure 1A,B) are usually characteristic of early apoptotic cells. ${ }^{64}$ The induction of formation of mutants with a petite phenotype, as described above (Figure 5A), together with our previous results, which have shown that cells from a derivative $\rho^{0}$ mutant (without mitochondrial DNA) presented reduced levels of ROS and increased resistance to $\mathrm{NiO} N P s,{ }^{19}$ reinforces the possibility of an active role of mitochondria in the execution of an apoptotic program in response to exposure to $\mathrm{NiO}$ NPs.

Previous studies have described the requirement of the apoptosis inducing factor (Aiflp) in RCD induced by several stimuli. $^{20,45}$ Yeast cells without the mitochondrial proapoptotic factor Aif1p (aif1 $\Delta$ strain) presented higher resistance to NiO NPs (Figure 4), which suggests the participation of the Aiflp in the execution of RCD by apoptosis. This result also supports the role of mitochondria in apoptosis induced by $\mathrm{NiO} \mathrm{NPs}$. It is also described that in response to apoptotic stimuli, Aiflp is released from mitochondria and translocated into the nucleus, where chromatin condensation and DNA fragmentation are carried out and, thus, cellular demise is provoked. ${ }^{52}$ Modifications of the nucleus morphology (including the increase in the number of cells with ring- and kidney-shaped condensed chromatin) were observed in yeast cells treated with NPs (Figure 2D); these facts are compatible with the possibility of the participation of Aif1 as the executioner of NiO-induced RCD.

In summary, it was shown that exposure of yeast cells to $\mathrm{NiO}$ NPs induces cell death, which exhibits several typical features of RCD by apoptosis: (i) loss of proliferation capacity dependent on the participation of cellular machinery, namely, de novo protein synthesis and the activation of the metacaspase Ycalp; (ii) externalization of PS at the surface of the cytoplasmic membrane in cells retaining membrane integrity; and (iii) modification of nucleus morphology. Other further insights were also obtained, namely, mitochondrial membrane potential dissipation, induction of petite mutants, and the participation of the Aiflp; these facts support the involvement of mitochondria in the RCD induced by NiO NPs. An overview of the sequence of detrimental effects associated with $\mathrm{NiO}$ NPs induced in S. cerevisiae is presented in Figure 6.

In conclusion, the results presented here strongly suggest that NiO NPs induce caspase- and mitochondrial dependent $\mathrm{RCD}$ by apoptosis in S. cerevisiae. Using this yeast, as a model organism, new information's about the events underlying cellular death, more specifically, about the role of mitochondria in the apoptosis induced by $\mathrm{NiO} \mathrm{NPs}$, are given. The data presented might contribute to the understanding and prevention of the possible detrimental effects associated with the use of NiO NPs.

\section{ASSOCIATED CONTENT}

\section{S Supporting Information}

The Supporting Information is available free of charge on the ACS Publications website at DOI: 10.1021/acs.chemrestox. 8 b00265.

Comparison of the evolution of cell death, plasma membrane integrity, and double staining $\left[\mathrm{DiOC}_{6}(3)\right.$ and propidium iodide] of $S$. cerevisiae BY4741 exposed to $\mathrm{NiO}(\mathrm{PDF})$

\section{AUTHOR INFORMATION}

\section{Corresponding Author}

*E-mail: evs@isep.ipp.pt. Telephone: 351-22-8340500.

ORCID ${ }^{\circ}$

Eduardo V. Soares: 0000-0003-2280-5291

Funding

This work was performed in the framework of the financing by the Portuguese Foundation for Science and Technology (FCT) under the scope of the strategic funding of the UID/ BIO/04469/2013 unit, COMPETE 2020 (POCI-01-0145FEDER-006684), and BioTecNorte operation (NORTE-010145-FEDER-000004) funded by the European Regional Development Fund under the scope of Norte2020-Programa Operacional Regional do Norte and LAQV (UID/QUI/ 50006/2013-POCI/01/0145/FEDER/007265) with financial support from FCT/MEC through national funds and cofinanced by FEDER, under Partnership Agreement PT2020. C.A.S. gratefully acknowledges the doctoral grant (SFRH/BD/ 101452/2014) from FCT.

\section{Notes}

The authors declare no competing financial interest. 


\section{REFERENCES}

(1) EPRUI (2017) Nanoparticles \& microspheres, Nano nickel oxide. https://www.nanoparticles-microspheres.com/Products/NanoNickel-Oxide.html (accessed October 30, 2017).

(2) Capasso, L., Camatini, M., and Gualtieri, M. (2014) Nickel oxide nanoparticles induce inflammation and genotoxic effect in lung epithelial cells. Toxicol. Lett. 226, 28-34.

(3) Cho, W.-S., Duffin, R., Poland, C. A., Howie, S. E. M., MacNee, W., Bradley, M., Megson, I. L., and Donaldson, K. (2010) Metal oxide nanoparticles induce unique inflammatory foot prints in the lung: important implications for nanoparticles testing. Environ. Health Perspect. 118, 1699-1706.

(4) Horie, M., Nishio, K., Fujita, K., Kato, H., Nakamura, A., Kinugasa, S., Endoh, S., Miyauchi, A., Yamamoto, K., Murayama, H., Niki, E., Iwahashi, H., Yoshida, Y., and Nakanishi, J. (2009) Ultrafine $\mathrm{NiO}$ particles induce cytotoxicity in vitro by cellular uptake and subsequent Ni(II) release. Chem. Res. Toxicol. 22, 1415-1426.

(5) Magaye, R., and Zhao, J. (2012) Recent progress in studies of metallic nickel and nickel-based nanoparticles' genotoxicity and carcinogenicity. Environ. Toxicol. Pharmacol. 34, 644-650.

(6) IARC monography on the evolution of carcinogenic risks to humans, Vol. 49 (1990) International Agency for Research on Cancer, Lyon, France.

(7) Galluzzi, L., Bravo-San Pedro, J. M., Vitale, I., Aaronson, S. A., Abrams, J. M., Adam, D., Alnemri, E. S., Altucci, L., Andrews, D., Annicchiarico-Petruzzelli, M., Baehrecke, E. H., Bazan, N. G., Bertrand, M. J., Bianchi, K., Blagosklonny, M. V., Blomgren, K., Borner, C., Bredesen, D. E., Brenner, C., Campanella, M., Candi, E., Cecconi, F., Chan, F. K., Chandel, N. S., Cheng, E. H., Chipuk, J. E., Cidlowski, J. A., Ciechanover, A., Dawson, T. M., Dawson, V. L., De Laurenzi, V., De Maria, R., Debatin, K. M., Di Daniele, N., Dixit, V. M., Dynlacht, B. D., El-Deiry, W. S., Fimia, G. M., Flavell, R. A., Fulda, S., Garrido, C., Gougeon, M. L., Green, D. R., Gronemeyer, H., Hajnoczky, G., Hardwick, J. M., Hengartner, M. O., Ichijo, H., Joseph, B., Jost, P. J., Kaufmann, T., Kepp, O., Klionsky, D. J., Knight, R. A., Kumar, S., Lemasters, J. J., Levine, B., Linkermann, A., Lipton, S. A., Lockshin, R. A., López-Otín, C., Lugli, E., Madeo, F., Malorni, W., Marine, J. C., Martin, S. J., Martinou, J. C., Medema, J. P., Meier, P., Melino, S., Mizushima, N., Moll, U., Muñoz-Pinedo, C., Nuñez, G., Oberst, A., Panaretakis, T., Penninger, J. M., Peter, M. E., Piacentini, M., Pinton, P., Prehn, J. H., Puthalakath, H., Rabinovich, G. A., Ravichandran, K. S., Rizzuto, R., Rodrigues, C. M., Rubinsztein, D. C., Rudel, T., Shi, Y., Simon, H. U., Stockwell, B. R., Szabadkai, G., Tait, S. W., Tang, H. L., Tavernarakis, N., Tsujimoto, Y., Vanden Berghe, T., Vandenabeele, P., Villunger, A., Wagner, E. F., Walczak, H., White, E., Wood, W., Yuan, J., Zakeri, Z., Zhivotovsky, B., Melino, G., and Kroemer, G. (2015) Essential versus accessory aspects of cell death: recommendations of the NCCD 2015. Cell Death Differ. 22, 58-73.

(8) Galluzzi, L., Vitale, I., Aaronson, S. A., Abrams, J. M., Adam, D., Agostinis, P., Alnemri, E. S., Altucci, L., Amelio, I., Andrews, D. W., Annicchiarico-Petruzzelli, M., Antonov, A. V., Arama, E., Baehrecke, E. H., Barlev, N. A., Bazan, N. G., Bernassola, F., Bertrand, M. J. M., Bianchi, K., Blagosklonny, M. V., Blomgren, K., Borner, C., Boya, P., Brenner, C., Campanella, M., Candi, E., Carmona-Gutierrez, D., Cecconi, F., Chan, F. K. M., Chandel, N. S., Cheng, E. H., Chipuk, J. E., Cidlowski, J. A., Ciechanover, A., Cohen, G. M., Conrad, M., Cubillos-Ruiz, J. R., Czabotar, P. E., D’Angiolella, V., Dawson, T. M., Dawson, V. L., De Laurenzi, V., De Maria, R., Debatin, K. M., DeBerardinis, R. J., Deshmukh, M., Di Daniele, N., Di Virgilio, F., Dixit, V. M., Dixon, S. J., Duckett, C. S., Dynlacht, B. D., El-Deiry, W. S., Elrod, J. W., Fimia, G. M., Fulda, S., García-Sáez, A. J., Garg, A. D., Garrido, C., Gavathiotis, E., Golstein, P., Gottlieb, E., Green, D. R. Greene, L. A., Gronemeyer, H., Gross, A., Hajnoczky, G., Hardwick, J. M., Harris, I. S., Hengartner, M. O., Hetz, C., Ichijo, H., Jaattela, M., Joseph, B., Jost, P. J., Juin, P. P., Kaiser, W. J., Karin, M., Kaufmann, T., Kepp, O., Kimchi, A., Kitsis, R. N., Klionsky, D. J., Knight, R. A., Kumar, S., Lee, S. W., Lemasters, J. J., Levine, B., Linkermann, A., Lipton, S. A., Lockshin, R. A., Lopez-Otin, C., Lowe, S. W., Luedde, T., Lugli, E., MacFarlane, M., Madeo, F., Malewicz, M., Malorni, W.,
Manic, G., Marine, J. C., Martin, S. J., Martinou, J. C., Medema, J. P., Mehlen, P., Meier, P., Melino, S., Miao, E. A., Molkentin, J. D., Moll, U. M., Munoz-Pinedo, C., Nagata, S., Nunez, G., Oberst, A., Oren, M., Overholtzer, M., Pagano, M., Panaretakis, T., Pasparakis, M., Penninger, J. M., Pereira, D. M., Pervaiz, S., Peter, M. E., Piacentini, M., Pinton, P., Prehn, J. H. M., Puthalakath, H., Rabinovich, G. A., Rehm, M., Rizzuto, R., Rodrigues, C. M. P., Rubinsztein, D. C., Rudel, T., Ryan, K. M., Sayan, E., Scorrano, L., Shao, F., Shi, Y. F., Silke, J., Simon, H. U., Sistigu, A., Stockwell, B. R., Strasser, A., Szabadkai, G., Tait, S. W. G., Tang, D. L., Tavernarakis, N., Thorburn, A., Tsujimoto, Y., Turk, B., Vanden Berghe, T., Vandenabeele, P., Vander Heiden, M. G., Villunger, A., Virgin, H. W., Vousden, K. H., Vucic, D., Wagner, E. F., Walczak, H., Wallach, D., Wang, Y., Wells, J. A., Wood, W., Yuan, J. Y., Zakeri, Z., Zhivotovsky, B., Zitvogel, L., Melino, G., and Kroemer, G. (2018) Molecular mechanisms of cell death: recommendations of the Nomenclature Committee on Cell Death 2018. Cell Death Differ. 25, 486-541.

(9) Munoz, A. J., Wanichthanarak, K., Meza, E., and Petranovic, D. (2012) Systems biology of yeast cell death. FEMS Yeast Res. 12, 249265

(10) Duan, W. X., He, M. D., Mao, L., Qian, F. H., Li, Y. M., Pi, H. F., Liu, C., Chen, C. H., Lu, Y. H., Cao, Z. W., Zhang, L., Yu, Z. P., and Zhou, Z. (2015) NiO nanoparticles induce apoptosis through repressing SIRT1 in human bronchial epithelial cells. Toxicol. Appl. Pharmacol. 286, 80-91.

(11) Pietruska, J. R., Liu, X., Smith, A., McNeil, K., Weston, P., Zhitkovich, A., Hurt, R., and Kane, A. B. (2011) Bioavailability, intracellular mobilization of nickel, and HIF-1a activation in human lung epithelial cells exposed to metallic nickel and nickel oxide nanoparticles. Toxicol. Sci. 124, 138-148.

(12) Ahamed, M., Ali, D., Alhadlaq, H. A., and Akhtar, M. J. (2013) Nickel oxide nanoparticles exert cytotoxicity via oxidative stress and induce apoptotic response in human liver cells (HepG2). Chemosphere 93, 2514-2522.

(13) Saquib, Q., Siddiqui, M. A., Ahmad, J., Ansari, S. M., Faisal, M., Wahab, R., Alatar, A. A., Al-Khedhairy, A. A., and Musarrat, J. (2018) Nickel oxide nanoparticles induced transcriptomic alterations in HepG2 cells. Adv. Exp. Med. Biol. 1048, 163-174.

(14) Abudayyak, M., Guzel, E., and Ozhan, G. (2017) Nickel oxide nanoparticles are highly toxic to SH-SY5Y neuronal cells. Neurochem. Int. 108, 7-14.

(15) Mirisola, M. G., Braun, R. J., and Petranovic, D. (2014) Approaches to study yeast cell aging and death. FEMS Yeast Res. 14, 109-118.

(16) Wloch-Salamon, D. M., and Bem, A. E. (2013) Types of cell death and methods of their detection in yeast Saccharomyces cerevisiae. J. Appl. Microbiol. 114, 287-298.

(17) Karathia, H., Vilaprinyo, E., Sorribas, A., and Alves, R. (2011) Sacharomyces cerevisiae as a model organism: a comparative study. PLoS One 6, e16015.

(18) Sousa, C. A., Soares, H. M. V. M., and Soares, E. V. (2018) Nickel oxide $(\mathrm{NiO})$ nanoparticles disturb physiology and induce cell death in the yeast Saccharomyces cerevisiae. Appl. Microbiol. Biotechnol. 102, 2827-2838.

(19) Sousa, C. A., Soares, H. M. V. M., and Soares, E. V. (2018) Nickel oxide $(\mathrm{NiO})$ nanoparticles induce loss of cell viability in yeast mediated by oxidative stress. Chem. Res. Toxicol. 31, 658-665.

(20) Strich, R. (2015) Programmed cell death initiation and execution in budding yeast. Genetics 200, 1003-1014.

(21) Amberg, D. C., Burke, D. J., and Strathern, J. N. (2005) Appendix A - media. In Methods in Yeast Genetics: A Cold Spring Harbor Laboratory Course Manual, pp 199-209, Cold Spring Harbor Laboratory Press, Plainview, NY.

(22) Epps, D. E., Wolfe, M. L., and Groppi, V. (1994) Characterization of the steady-state and dynamic fluorescence properties of the potential-sensitive dye bis-(1,3-dibutylbarbituric acid) trimethine oxonol $\left(\operatorname{DiBAC}_{4}(3)\right)$ in model systems and cells. Chem. Phys. Lipids 69, 137-150. 
(23) Vermes, I., Haanen, C., Steffensnakken, H., and Reutellingsperger, C. (1995) A novel assay for apoptosis - flow cytometric detection of phosphatidylserine expression on early apoptotic cells using fluorescein-labeled Annexin-V. J. Immunol. Methods 184, 39-51.

(24) Pozarowski, P., Grabarek, J., and Darzynkiewicz, Z. (2003) Flow cytometry of apoptosis. Current Protocols in Cytometry Supplement 25, 7.19.1-7.19.33.

(25) Rottenberg, H., and Wu, S. L. (1998) Quantitative assay by flow cytometry of the mitochondrial membrane potential in intact cells. Biochim. Biophys. Acta, Mol. Cell Res. 1404, 393-404.

(26) Bussche, J. V., and Soares, E. V. (2011) Lead induces oxidative stress and phenotypic markers of apoptosis in Saccharomyces cerevisiae. Appl. Microbiol. Biotechnol. 90, 679-687.

(27) Gomes, D. S., Pereira, M. D., Panek, A. D., Andrade, L. R., and Araujo Eleutherio, E. C. (2008) Apoptosis as a mechanism for removal of mutated cells of Saccharomyces cerevisiae: the role of Grx2 under cadmium exposure. Biochim. Biophys. Acta, Gen. Subj. 1780, $160-166$.

(28) Eki, T. (2018) Yeast-based genotoxicity tests for assessing DNA alterations and DNA stress responses: a 40-year overview. Appl. Microbiol. Biotechnol. 102, 2493-2507.

(29) Sousa, C. A., and Soares, E. V. (2014) Mitochondria are the main source and one of the targets of $\mathrm{Pb}$ (lead)-induced oxidative stress in the yeast Saccharomyces cerevisiae. Appl. Microbiol. Biotechnol. 98, 5153-5160.

(30) Madia, F., Wei, M., Yuan, V., Hu, J., Gattazzo, C., Pham, P., Goodman, M. F., and Longo, V. D. (2009) Oncogene homologue Sch9 promotes age-dependent mutations by a superoxide and Rev1/ Pol zeta-dependent mechanism. J. Cell Biol. 186, 509-523.

(31) Davey, H. M., and Hexley, P. (2011) Red but not dead? Membranes of stressed Saccharomyces cerevisiae are permeable to propidium iodide. Environ. Microbiol. 13, 163-171.

(32) Carmona-Gutierrez, D., Bauer, M. A., Zimmermann, A., Aguilera, A., Austriaco, N., Ayscough, K., Balzan, R., Bar-Nun, S., Barrientos, A., Belenky, P., Blondel, M., Braun, R. J., Breitenbach, M., Burhans, W. C., Buttner, S., Cavalieri, D., Chang, M., Cooper, K. F., Corte-Real, M., Costa, V., Cullin, C., Dawes, I., Dengjel, J., Dickman, M. B., Eisenberg, T., Fahrenkrog, B., Fasel, N., Frohlich, K. U., Gargouri, A., Giannattasio, S., Goffrini, P., Gourlay, C. W., Grant, C. M., Greenwood, M. T., Guaragnella, N., Heger, T., Heinisch, J., Herker, E., Herrmann, J. M., Hofer, S., Jimenez-Ruiz, A., Jungwirth, H., Kainz, K., Kontoyiannis, D. P., Ludovico, P., Manon, S., Martegani, E., Mazzoni, C., Megeney, L. A., Meisinger, C., Nielsen, J., Nystrom, T., Osiewacz, H. D., Outeiro, T. F., Park, H. O., Pendl, T., Petranovic, D., Picot, S., Polcic, P., Powers, T., Ramsdale, M., Rinnerthaler, M., Rockenfeller, P., Ruckenstuhl, C., Schaffrath, R., Segovia, M., Severin, F. F., Sharon, A., Sigrist, S. J., Sommer-Ruck, C., Sousa, M. J., Thevelein, J. M., Thevissen, K., Titorenko, V., Toledano, M. B., Tuite, M., Vogtle, F. N., Westermann, B., Winderickx, J., Wissing, S., Wolfl, S., Zhang, Z. J. J., Zhao, R. Y., Zhou, B., Galluzzi, L., Kroemer, G., and Madeo, F. (2018) Guidelines and recommendations on yeast cell death nomenclature. Microb. Cell 5, 4-31.

(33) Davey, H. M., Kell, D. B., Weichart, D. H., and Kaprelyants, A. S. (2004) Estimation of microbial viability using flow cytometry. Current Protocols in Cytometry Supplement 29, 11.13.11-11.13.21.

(34) Novo, D. J., Perlmutter, N. G., Hunt, R. H., and Shapiro, H. M. (2000) Multiparameter flow cytometric analysis of antibiotic effects on membrane potential, membrane permeability, and bacterial counts of Staphylococcus aureus and Micrococcus luteus. Antimicrob. Agents Chemother. 44, 827-834.

(35) Davey, H. M. (2011) Life, death, and in-between: meanings and methods in microbiology. Appl. Environ. Microbiol. 77, 55715576.

(36) Eisenberg, T., Carmona-Gutierrez, D., Buettner, S., Tavernarakis, N., and Madeo, F. (2010) Necrosis in yeast. Apoptosis $15,257-268$.
(37) Kitagaki, H., Araki, Y., Funato, K., and Shimoi, H. (2007) Ethanol-induced death in yeast exhibits features of apoptosis mediated by mitochondrial fission pathway. FEBS Lett. 581, 2935-2942.

(38) Ludovico, P., Rodrigues, F., Almeida, A., Silva, M. T., Barrientos, A., and Corte-Real, M. (2002) Cytochrome c release and mitochondria involvement in programmed cell death induced by acetic acid in Saccharomyces cerevisiae. Mol. Biol. Cell 13, 2598-2606.

(39) Ludovico, P., Sousa, M. J., Silva, M. T., Leão, C., and CôrteReal, M. (2001) Saccharomyces cerevisiae commits to a programmed cell death process in response to acetic acid. Microbiology 147, 24092415.

(40) Madeo, F., Frohlich, E., Ligr, M., Grey, M., Sigrist, S. J., Wolf, D. H., and Frohlich, K. U. (1999) Oxygen stress: a regulator of apoptosis in yeast. J. Cell Biol. 145, 757-767.

(41) Acosta-Zaldivar, M., Andres, M. T., Rego, A., Pereira, C. S., Fierro, J. F., and Corte-Real, M. (2016) Human lactoferrin triggers a mitochondrial- and caspase-dependent regulated cell death in Saccharomyces cerevisiae. Apoptosis 21, 163-173.

(42) Smith, A. (2000) Oxford dictionary of biochemistry and molecular biology, pp 149-150, Oxford University Press, Oxford, U.K.

(43) Martelli, A. M., Zweyer, M., Ochs, R. L., Tazzari, P. L., Tabellini, G., Narducci, P., and Bortul, R. (2001) Nuclear apoptotic changes: an overview. J. Cell. Biochem. 82, 634-646.

(44) Guaragnella, N., Zdralević, M., Antonacci, L., Passarella, S., Marra, E., and Giannattasio, S. (2012) The role of mitochondria in yeast programmed cell death. Front. Oncol. 2, 70.

(45) Pereira, C., Silva, R. D., Saraiva, L., Johansson, B., Sousa, M. J., and Corte-Real, M. (2008) Mitochondria-dependent apoptosis in yeast. Biochim. Biophys. Acta, Mol. Cell Res. 1783, 1286-1302.

(46) Ligr, M., Madeo, F., Frohlich, E., Hilt, W., Frohlich, K. U., and Wolf, D. H. (1998) Mammalian Bax triggers apoptotic changes in yeast. FEBS Lett. 438, 61-65.

(47) Manon, S., Chaudhuri, B., and Guérin, M. (1997) Release of cytochrome $\mathrm{c}$ and decrease of cytochrome $\mathrm{c}$ oxidase in Bax-expressing yeast cells, and prevention of these effects by coexpression of Bcl-xL. FEBS Lett. 415, 29-32.

(48) Perry, S. W., Norman, J. P., Barbieri, J., Brown, E. B., and Gelbard, H. A. (2011) Mitochondrial membrane potential probes and the proton gradient: a practical usage guide. BioTechniques 50, 98115.

(49) Carmona-Gutierrez, D., Eisenberg, T., Buttner, S., Meisinger, C., Kroemer, G., and Madeo, F. (2010) Apoptosis in yeast: triggers, pathways, subroutines. Cell Death Differ. 17, 763-773.

(50) Mazzoni, C., and Falcone, C. (2008) Caspase-dependent apoptosis in yeast. Biochim. Biophys. Acta, Mol. Cell Res. 1783, 13201327.

(51) Madeo, F., Herker, E., Maldener, C., Wissing, S., Lachelt, S., Herlan, M., Fehr, M., Lauber, K., Sigrist, S. J., Wesselborg, S., and Frohlich, K. U. (2002) A caspase-related protease regulates apoptosis in yeast. Mol. Cell 9, 911-917.

(52) Wissing, S., Ludovico, P., Herker, E., Buttner, S., Engelhardt, S. M., Decker, T., Link, A., Proksch, A., Rodrigues, F., Corte-Real, M., Frohlich, K. U., Manns, J., Cande, C., Sigrist, S. J., Kroemer, G., and Madeo, F. (2004) An AIF orthologue regulates apoptosis in yeast. J. Cell Biol. 166, 969-974.

(53) de Zamaroczy, M., and Bernardi, G. (1985) Sequence organization of the mitochondrial genome of yeast - a review. Gene $37,1-17$.

(54) Evans, I. H. (1983) Molecular genetic aspects of yeast mitochondria. In Yeast genetics: Fundamental and Applied Aspects (Spencer, J. F. T., Spencer, D. M., and Smith, A. R. W., Eds.) pp 269370, Springer, New York.

(55) Yazgan, O., and Krebs, J. E. (2012) Mitochondrial and nuclear genomic integrity after oxidative damage in Saccharomyces cerevisiae. Front. Biosci., Landmark Ed. 17, 1079-1093.

(56) Richter, C., Park, J. W., and Ames, B. N. (1988) Normal oxidative damage to mitochondrial and nuclear-DNA is extensive. Proc. Natl. Acad. Sci. U. S. A. 85, 6465-6467. 
(57) Clark-Walker, G. D., McArthur, C. R., and Daley, D. J. (1981) Does mitochondrial DNA length influence the frequency of spontaneous petite mutants in yeasts? Curr. Genet. 4, 7-12.

(58) Hu, J., Wei, M., Mirisola, M. G., and Longo, V. D. (2013) Assessing chronological aging in Saccharomyces cerevisiae. Methods Mol. Biol. 965, 463-472.

(59) Letavayová, L., Vlasáková, D., Spallholz, J. E., Brozmanová, J., and Chovanec, M. (2008) Toxicity and mutagenicity of selenium compounds in Saccharomyces cerevisiae. Mutat. Res., Fundam. Mol. Mech. Mutagen. 638, 1-10.

(60) Siddiqui, M. A., Ahamed, M., Ahmad, J., Majeed Khan, M. A., Musarrat, J., Al-Khedhairy, A. A., and Alrokayan, S. A. (2012) Nickel oxide nanoparticles induce cytotoxicity, oxidative stress and apoptosis in cultured human cells that is abrogated by the dietary antioxidant curcumin. Food Chem. Toxicol. 50, 641-647.

(61) Arrigoni, O., and De Tullio, M. C. (2002) Ascorbic acid: much more than just an antioxidant. Biochim. Biophys. Acta, Gen. Subj. 1569, $1-9$.

(62) Nimse, S. B., and Pal, D. (2015) Free radicals, natural antioxidants, and their reaction mechanisms. RSC Adv. 5, 2798628006.

(63) Xu, Y., Gu, Y., and Qian, S. Y. (2012) An advanced electron spin resonance (ESR) spin-trapping and LC/(ESR)/MS technique for the study of lipid peroxidation. Int. J. Mol. Sci. 13, 14648-14666. (64) Cottet-Rousselle, C., Ronot, X., Leverve, X., and Mayol, J. F. (2011) Cytometric assessment of mitochondria using fluorescent probes. Cytometry, Part A 79A, 405-425. 